\title{
Problematika Tugu Yogyakarta dari Aspek Fungsi dan Makna
}

Lutse Lambert Daniel Morin

Jurusan Seni Murni, Fakultas Seni Rupa, Institut Seni Indonesia Yogyakarta

Jl. Parangtritis Km 6,5 Bantul, Yogyakarta 55001

Tlp.082220344996, E-mail: lutsemorin@yahoo.co.id

Volume 1 Nomor 2,

Oktober 2014: 135-148

\begin{abstract}
Penelitian ini bertujuan untuk memahami fungsi dan makna bangunan Tugu Yogyakarta. Tugu Yogyakarta adalah bangunan berbentuk prisma segi empat dan menggunakan unsur-unsur seni rupa berupa garis, titik, warna, dan bidang sebagai dasar pembuatannya yang memiliki makna-makna yang dapat dipahami berdasarkan telaah filosofi masyarakat Jawa. Penelitian ini menggunakan metode penelitian kualitatif dengan pendekatan ikonografi. Pemaknaan Tugu Yogyakarta mengalami pergeseran setiap generasi seiring dengan perubahan budaya masyarakat Yogyakarta. Tugu telah berubah dan mulai kehilangan nilai kesakralannya atau mengalamai disakralisasi. Filosofi manunggaling kawula lan Gusti telah hilang dan tidak tercermin pada tugu saat ini. Sehingga bagi Keraton, tugu saat ini tidak bermakna. Tugu bukan lagi menjadi salah satu simbol keraton tetapi lebih pada ikon Kota Yogyakarta saja.
\end{abstract}

Kata kunci: Tugu Yogyakarta, golong gilig, makna, filosofi Jawa, pergeseran budaya dan perubahan budaya

\section{ABSTRAK}

Tugu Yogyakarta and its Problems on the Aspects of Function and Meaning. The research is aimed to understand the function and meaning of Tugu Yogyakarta. Tugu Yogyakarta is a rectangular prism-shaped building and uses the meanings implied in the visual art elements such as lines, dots, color, and the surfaces as they are the basis in the making process that can be understood by scrutinizing the Javanese society philosophy. It is a qualitative research using the iconographic approach. The shifting meaning of Tugu Yogyakarta has gradually been experienced by Yogyakarta people which goes along with the cultural changes. It has unfortunately changed and started losing its sacred value. 'Manunggaling kawulo lan Gusti' as its philosophy has gone and no longer reflected by the monument. Therefore, Tugu Yogyakarta has no meaning today. It is no longer one of the Keraton Yogyakarta symbols, but merely as the icon of Yogyakarta city instead.

Keywords: Tugu Yogyakarta, golong gilig, meaning, Javanese philosophy, cultural shifts and changes 


\section{Pendahuluan}

Sejarah berdirinya Keraton Ngayogyakarta Hadiningrat menghadirkan beberapa budaya yang berwujud artefak. Sebagai perwujudannya adalah tugu, Panggung Krapyak, plengkung, benteng, dan keraton. Artefak-artefak ini berfungsi sebagai penanda keberadaan Yogyakarta.

Posisi Tugu Yogyakarta sekarang berada di tengah perempatan jalan besar, yaitu yang membujur ke utara adalah Jalan AM Sangaji ke timur Jalan Jenderal Sudirman, ke selatan Jalan Pangeran Mangkubumi-Malioboro, dan ke barat Jalan Pangeran Diponegara. Bentuk Tugu pada saat ini persegi, di setiap sisinya terdapat prasasti yang menunjukkan siapa saja yang terlibat dalam renovasi itu. Ketinggian Tugu saat ini dua belas meter di atas permukaan tanah akibat renovasi yang dilakukan terhadap tugu. Tugu mempunyai empat bentuk fisik, yaitu kotak berundak pada bagian bawah sebagai landasan, kotak dengan prasasti pada setiap sisinya, piramid tumpul dengan ornamen yang menempel pada setiap sisinya, dan puncak tugu berbentuk kerucut ulir. Bentuk-bentuk tersebut dikombinasi dengan hiasan-hiasan yang memiliki simbol Jawa seperti keris (Hasta Karya), panah, daun "waru", daun loto, daun teratai, janget kinatelon, bentuk praba, bintang sudut enam, deretan titik atau ceceg, wajik, bentuk air tetes, dan setiliran. Selain itu, terdapat tulisan Jawa pada keempat sisinya. Warna yang tampak merupakan kombinasi cokelat hitam dan terdapat warna emas pada puncak Tugu Yogyakarta. Bentuk tugu secara geometris terdiri dari balok, prisma, dan untiran seperti kuncup. Pada bagian tubuh tugu terdapat prasasti tulisan Jawa dengan menggunakan warna cokelat.

Perubahan bentuk tugu ini sesungguhnya sudah dimulai dari awal didirikannya tugu saat ini yaitu pada tanggal 10 Juni 1867. Terjadinya perubahan bentuk tugu ini diawali dengan adanya peristiwa terpotongnya Tugu Golong-Gilig sepertiga bagian akibat gempa pada tahun EHE 1284 $\mathrm{H}$ atau 1796 Tahun Jawa sekitar pukul 05.00 pagi. Pendirian kembali tugu adalah Opzichter van Waterstaat/Kepala Dinas Pekerjaan Umum, JWS van Brussel, di bawah pengawasan Pepatih Dalem Kanjeng Raden Adipati Danurejo V. Tugu kemudian diresmikan HB VII pada 3 Oktober 1889 atau 7 Sapar 1819 Tahun Jawa. Oleh pemerintah Belanda, tugu itu disebut De Witte Paal (Tugu Putih). Penamaan tersebut didasarkan pada fungsi tugu sebagai paal atau tonggak yang dicat/dikapur putih hingga tampak jelas dari kejauhan (Upacara Tradisional Jumenengan, 1995:116).

Bentuk Tugu saat ini telah mengalami beberapa kali renovasi dan pemugaran. Mulai dengan pemberian batas-batas luar, warna Tugu, dan jalur hijau yang dulu pernah mengelilingi tugu. Renovasi ini mengakibatnya ketinggian Tugu saat ini berkurang, menjadi dua belas meter.

Dalam hal makna, Tugu juga telah berubah dan mulai kehilangan nilai kesakralannya. Banyak demonstrasi yang dilakukan di sekitar Tugu. Pada malam hari, Tugu sering dijadikan tempat berfotofoto ataupun duduk-duduk meskipun telah diberi peringatan untuk tidak duduk-duduk di kaki bawah Tugu ataupun mencoret-coret Tugu.

Bentuk tugu saat ini sesungguhnya merupakan pengubahan Tugu Golong-Gilig yang didirikan pada zaman dulu oleh Sri Sultan Hamengku Buwana I pada tahun 1755. Bagian dasar Tugu berbentuk persegi, atasnya berbentuk silinder dengan puncak berbentuk bola bulat. Tinggi Tugu pada awal didirikan adalah dua puluh lima meter. Nama Golong-Gilig diambil berdasarkan bentuknya, yaitu pada puncaknya berbentuk golong (bulat/bola) dan bagian tiangnya yang berbentuk gilig (silinder). Tidak banyak orang tahu apa dan bagaimana tugu pada waktu dahulu atau bentuk dan makna tugu pada awal didirikan oleh Sri Sultan Hamengku Buwana I.

Penelitian Tugu Yogyakarta ini lebih mendasarkan pada data-data yang berupa buku-buku atau catatan-catatan sejarah mengenai tugu antara lain Arti Kraton Yogyakarta (Brotodiningrat,1978), Sejarah Keraton Yogyakarta (Sabdacarakatama, 2009), Upacara Tradisional Jumenengan: Arti, Fungsi, dan Makna Lambang Suatu Studi Tentang Tradisi Kraton Yogyakarta (1995), Manunggaling Kawula Gusti: Pantheisme dan Monisme dalam Sastra Suluk Jawa (Zoetmulder, 1991), dan Buku 
Gambar Warna-Warni, koleksi Museum Sono Budoyo Yogyakarta.

Buku-buku tersebut menulis beberapa hal yang berkaitan dengan Tugu Yogyakarta sehingga dapat menjadi salah satu sumber data untuk menelaah lebih jauh mengenai bentuk dan makna Tugu Yogyakarta. Data-data yang disajikan dalam buku tersebut akan digunakan oleh penulis sebagai acuan untuk menjabarkan pemaknaan tugu tugu baik secara fungsi maupun makna yang pada saat ini sudah mulai dilupakan atau mengalami pergeseran pemaknaan makna dan fungsi tugu dari segi sejarah.

Selain sumber tertulis, penulis juga melakukan wawancara dengan K.R.T. H. Djatiningrat, S.H., Pengagem Tepas Dwarapura Ngayogyakarta Hadingrat Keraton Kilen Yogyakarta, Raden Riyo Yogo Kanowo Staf Humas Keraton di Yogyakarta, dan Sumitro Kerabat Puro Pakualaman. Hal ini dilakukan untuk mengetahui pandangan pemaknaan bentuk dan fungsi Tugu Yogyakarta dari sudut pandang Keraton Ngayogyakarta Hadingrat seba-gai pihak yang berkepentingan dan berhubungan langsung dengan Tugu Yogyakarta. Semua data baik yang tertulis maupun lisan, akan diolah dan dianalisis serta disajikan dalam bentuk deskriptif.

\section{Pembahasan}

Sejarah berdirinya Tugu Golong-Gilig memunculkan filosofi masyarakat Yogyakarta, yaitu manunggaling kawulo lan Gusti. Filosofi yang terdapat pada tugu saat ini telah jauh berbeda dari makna dan fungsi Tugu yang sesungguhnya. Hal ini menimbulkan suatu problematika tersendiri yang menarik untuk diungkap bagaimana pengungkapan makna tersebut banyak melibatkan tindakan interpretatif untuk mengartikan perbedaan makna dan fungsi tugu. Berdasarkan teori Panofsky (1955), Tugu Yogyakarta dapat dijabarkan sebagai berikut.

\section{Analisa Tahap Praikonografis Tugu Yogyakarta}

Tahapan ini dapat disebut sebagai pemahaman secara faktual dan ekspresional. Pemahaman ini didasarkan pada pengalaman setiap individu terhadap suatu objek dengan cara mengindentifikasi unsur artistik dari objek gambar (konfigurasi tertentu dari garis dan warna, atau bentuk dan material yang merepresentasikan objek keseharian tertentu), hubungan-hubungan yang terjadi pada objek dan identifikasi kualitas ekspresional tertentu dengan melakukan pengamatan pose atau gestur dari objek.

Tugu Yogyakarta sebagai salah satu benda seni yang berupa monumen di dalamnya terdapat beberapa bentuk, yaitu trap tiga berundak, segi empat, kubus, sudut segi enam, deretan titik-titik, wajikan, air tetes, segi delapan, sudut runcing, panah-panah vertikal, untiran, prisma segi delapan, garis, dan warna.

Warna Tugu Yogyakarta adalah putih dengan berwarna cokelat dan emas pada puncak. Pada prasasti berwarna coklat gelap dan huruf Jawa menggunakan warna emas seperti pada bentuk untiran yang berada di puncak tugu tersebut.

Bentuk-bentuk yang telah dipaparkan tersebut, mulai titik, garis, hingga prisma, merupakan unsur pembentuk visual sebuah benda seni yang merupakan hasil karya tangan manusia. Unsurunsur tersebut dapat dikatakan sebagai unsur pembentuk seni, yaitu bangun yang terbentuk dari bidang-bidang geometri.

"Ada empat macam gaya seni: gaya ketepatan objektif (the style of objective accuracy), gaya susunan formal (the style of formal order), gaya emosi (the style of emotion) dan gaya fantasi (the style offantasy)" (Feldman, 1967:225). Dilihat dari bentuknya, tugu memiliki kecenderungan bentuk yang masif dan formal.

\section{Analisa Tahap Ikonografis Tugu Yogyakarta}

Trap tiga berundak (gambar 1) merupakan sebuah bangun yang menjadi landasan atau dasar Tugu Yogyakarta. Bentuk ini merupakan lambang dari Tri Murti, yaitu kamadhatu, rupadhatu dan a rupadhatu, yang merupakan ajaran dari agama Budha. Bentuk ini juga mewakili tiga fungsi dari tugu. Fungsi yang pertama adalah sebagai lambang kekuatan sakral. Dikatakan demikian, karena konsep pembuatan sama seperti konsep pembuatan menhir yang pada zamannya digunakan sebagai tanda peringatan dan juga dianggap memiliki kekuatan tertentu. 
Fungsi yang kedua adalah sebagai pathok zona kebudayaan Keraton Yogyakarta. Zona tersebut terbentang dari Krapyak dan berakhir atau dibatasi oleh pathok di sebelah utara Keraton Yogyakarta yang disebut tugu. Fungsi yang ketiga adalah sebagai titik pandang dan konsentrasi.

Bentuk segi empat pada tugu (gambar 2) tervisualisasi dalam bentuk-bentuk dasar tugu yang berupa kubus yang terbentuk dari segi empat. Selain itu, segi empat juga membentuk ornamen, yaitu wajikan. Bentuk segi empat pada tugu digunakan sebagai lambang empat kiblat. Pemahaman tersebut sering dilengkapi dengan kiblat yang kelima, yaitu pancer yang bermakna bahwa ke mana pun manusia menuju, pasti selalu kembali kepada Tuhan. Secara harfiah, "kiblat papat lima pancer" bermakna "empat arah mata angin dan satu pusat". Jika diterjemahkan bisa bermakna keseimbangan alam. Dari sudut pemerintahan, empat kiblat lima pancer diartikan sebagai empat penjuru arah mata angin dengan raja sebagai pusatnya.

Bentuk kubus pada tugu (gambar 2) disusun dan ditata menjadi bentuk tiga berundak dari yang terbesar hingga yang terkecil dan dijadikan struktur bangunan terbawah dari tugu. Susunan ini mem-

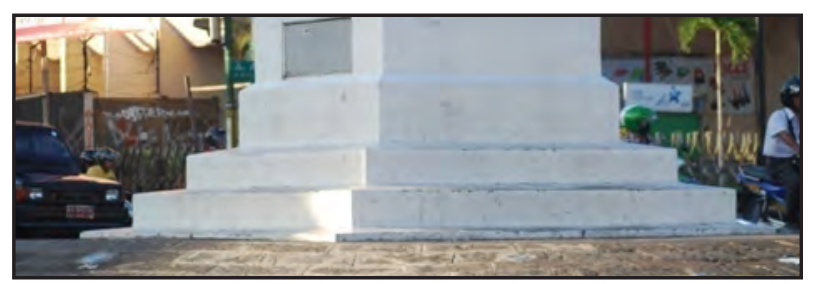

Gambar 1. Trap tiga berundak (landasan bersusun tiga). Foto diambil oleh penulis pada 21 Mei 2012.
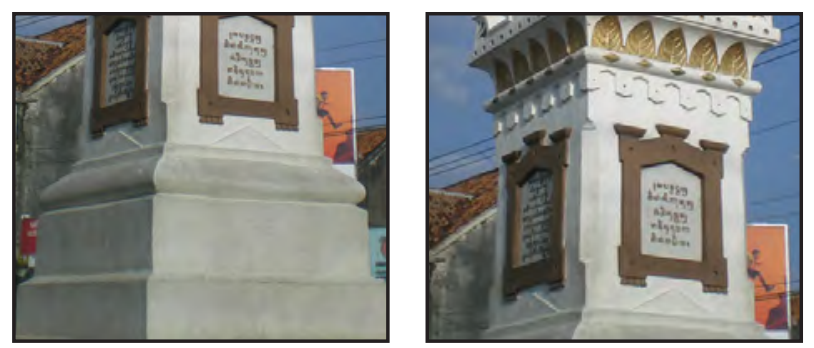

Gambar 2. Segi empat (kiri) berada di landasan dan kubus (kanan). Foto diambil oleh penulis pada 21 Mei 2012.

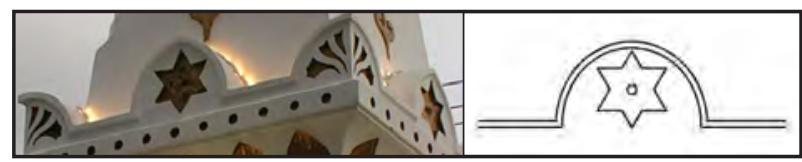

Gambar 3. Motif bintang. Foto dan grafis dibuat oleh penulis pada 9 November 2011. bentuk memiliki makna seperti yang disebutkan, yaitu kama, rupa dan a rupa.

Sudut enam yang terdapat dalam tugu (gambar 3) membentuk ornamen pada tugu. Sudut ini membentuk sebuah bintang. Sudut enam yang membentuk ornamen bintang pada tugu dapat diartikan sebagai arah menuju penerangan, yaitu menuju kepada pusat cahaya dari dunia dan kehidupan manusia, yaitu Tuhan Yang Maha Esa yang telah menciptakan cahaya sebagai penerang dunia ini.

Bentuk deretan titik-titik pada tugu (gambar 4) dimaknai sebagai lambang sebuah kesinambungan suatu perjalanan menuju kebenaran yang tidak pernah berhenti. Setiap manusia harus selalu berjalan menuju sebuah kebenaran.

Wajikan (gambar 5), berasal dari kata "wajik", yaitu sejenis makanan dari beras ketan yang dicampur gula kelapa. Sesuai dengan namanya, wajikan berupa bentukan belah ketupat. Pemaknaan bentuk ini sama dengan pemaknaan bentuk segi empat. Hal ini dikarenakan sesungguhnya bentuk wajikan atau belah ketupat merupakan bentuk dari segi empat yang diputar $90^{\circ}$ sehingga salah satu sudutnya berada di atas.

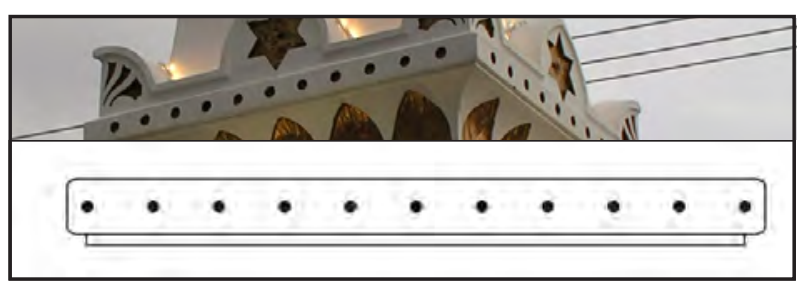

Gambar 4. Deretan titik-titik. Foto dan grafis dibuat oleh penulis pada 9 November 2011.

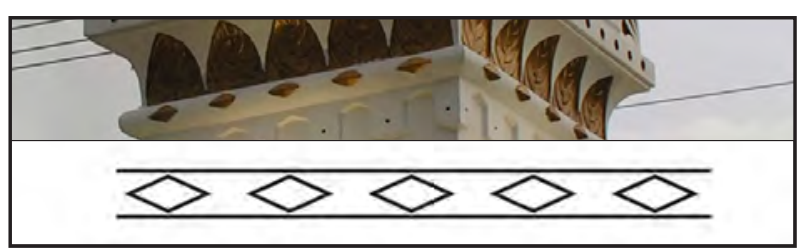

Gambar 5. Wajikan. Foto dan grafis dibuat oleh penulis pada 9 November 2011.

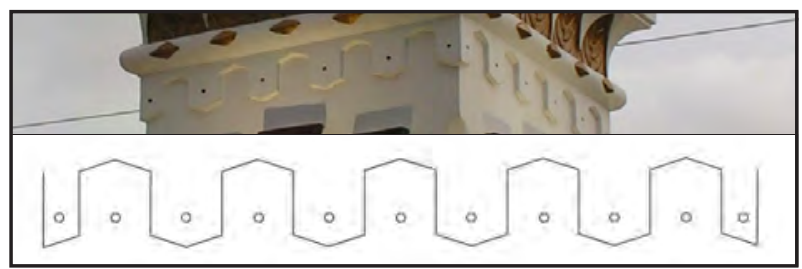

Gambar 6. Air tetes. Foto dan grafis dibuat oleh penulis pada 9 November 2011. 
Bentuk air tetes (gambar 6) ini menggambarkan salah satu filosofi masyarakat Jawa yang menggunakan falsafah air. Air terlihat lemah, namun memiliki kekuatan yang luar biasa. Tetes demi tetes air akan mampu menghancurkan batu. Dari filosofi tersebut, manusia bisa belajar bahwa hidup di dunia ini seharusnya lebih mengedepankan sifat lemah lembut seperti air.

Segi delapan dalam bentuk tugu (gambar 7) dimaknai sebagai hastha brata. Ajaran hasta brata mengajarkan kepada setiap orang yang menjadi pemimpin hendaknya memiliki delapan watak atau sifat keutamaan sejalan dengan alam.

Delapan watak atau sifat hasta brata adalah: (1) Mahambeg Mring Kismo, (2) Mahambeg Mring Warih, (3) Mahambeg Mring Samirana, (4) Mahambeg Mring Candra, (5) Mahambeg Mring Surya, (6) Mahambeg Mring Samodra, (7) Mahambeg Mring Wukir, dan (8) Mahambeg Mring Dahana (Purwadi, 2006:241-242).

Mahambeg Mring Kismo dapat diartikan sebagai seorang pemimpin diharapkan memiliki sifat-sifat keutamaan seperti bumi. Bumi itu sabar, memberi kepada siapa pun, menumbuhkan, mengubah busuk menjadi subur, tempat membuang segala hal baik ataupun buruk. Mahambeg Mring Warih yang berarti sebagai pemimpin diharapkan memiliki sifat-sifat keutamaan seperti air yang mampu memberikan kesejukan, ketenteraman, selalu turun atau mengarah ke bawah. Mahambeg

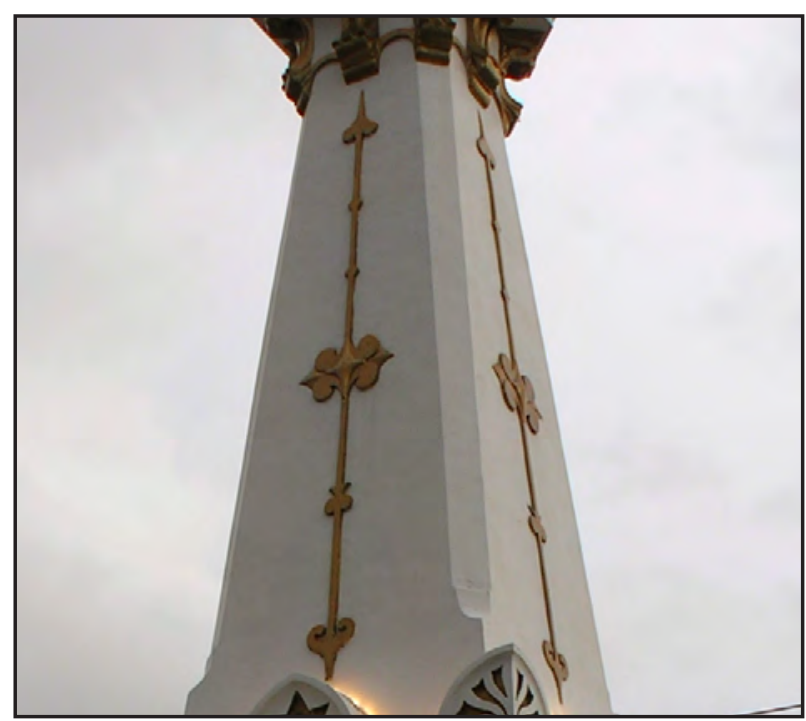

Gambar 7. Segi delapan yang membentuk prisma. Foto diambil oleh penulis pada 3 Desember 2011.
Mring Samirana yang berarti sebagai pemimpin diharapkan memiliki sifat-sifat keutamaan angin. Angin yang selalu ada di mana-mana di setiap tempat, adil, dan tidak membeda-bedakan, angin memberikan rasa nyaman atau kesejukan. Mahambeg Mring Candra berarti sebagai pemimpin diharapkan memiliki sifat-sifat keutamaan seperti bulan yang mampu memberikan penerangan secara lembut, memberi keindahan, adil bagi semua orang. Mahambeg Mring Surya yang berarti sebagai pemimpin diharapkan memiliki sifat-sifat keutamaan seperti matahari. Matahari memberi penerangan, sinarnya menghidupkan, di dalamnya terkandung makna ketegasan dan keaadilan. Mahambeg Mring Samodra yang berarti sebagai pemimpin diharapkan memiliki sifat-sifat keutamaan seperti laut dan samudra. Mahambeg Mring Wukir berarti sebagai pemimpin diharapkan memiliki sifa-sifat keutamaan seperti gunung yang mempunyai sifat kuat, kukuh, konsisten, indah. Mahambeg Mring Dahana yang berarti sebagai pemimpin diharapkan memiliki sifat-sifat keutamaan seperti api. Api mampu yang mampu membakar. Api yang bersifat tegas, namun juga bisa hangat.

Bentuk runcing yang terdapat dalam tugu (gambar 8), dapat diartikan sebagai titik kesempurnaan yang mutlak kepada Tuhan Yang Maha Esa. Tuhan sebagai puncak kekuasaan tertinggi atas jagad raya dan seisinya, dan atas hidup dan mati manusia. Tuhan sebagai puncak tujuan manusia.

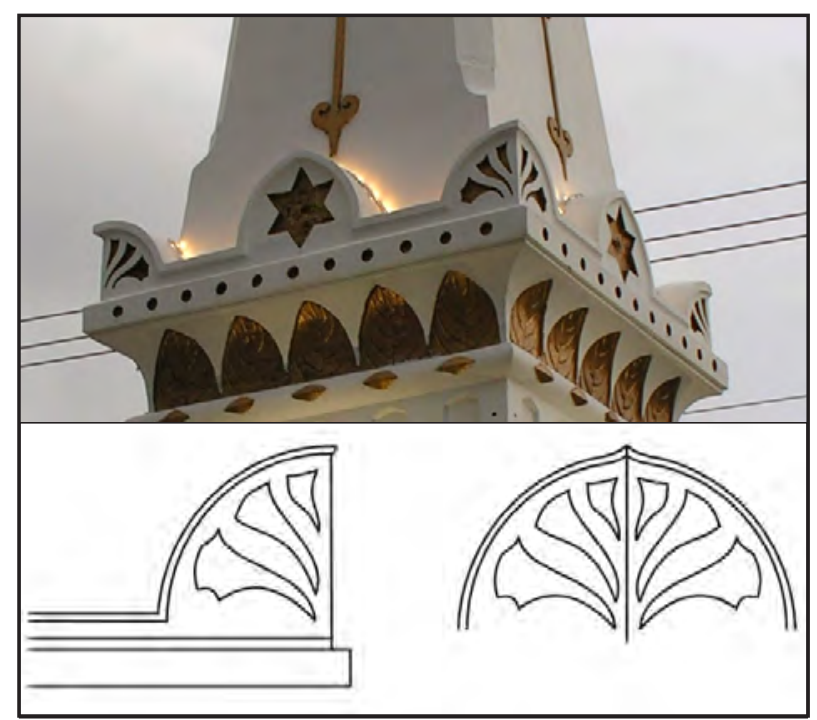

Gambar 8. Sudut runcing. Foto dan grafis dibuat oleh penulis pada 9 November 2011. 
Panah-panah vertikal yang ada pada ornamen tugu (gambar 9) adalah bentuk motif atau ornamen yang dipadu dengan daun loto. Penggambar-an ini dimaksudkan sebagai penggambaran motif tiang hias yang terdapat pada tiang-tiang Keraton Yogyakarta. Panah-panah vertikal merupakan bentuk senjata tajam. Bentuk ini sebagai penggambaran dari ketajaman perasaan manusia untuk mengetahui mana yang halal dan mana yang batal atau haram.

Untiran (gambar 10) dalam bentuk tugu digunakan sebagai lambang pikiran menuju nirwana. Bentuk ini dalam bahasa Sansekerta disebut sebagai triguna, yaitu sattvam, rajas, dan tamas.

Guna ada tiga perinciannya, yaitu sattvam, rajas, dan tamas. Ketiganya disebut triguna. Guna ini berpengaruh terhadap citta sehingga disebut citta sattva, citta rajas, dan citta tamas. Pada saat triguna bertemu dengan citta, lahirlah Bhudhi dan dari budhi lahirlah ahamkara, ahamkara dibedakan menjadi tiga, yaitu ahamkara waikreta, taijasa, dan bhutadi (Siwa Tatwa, 2004: 19).

Dengan demikian, triguna ini akan memberi pengaruh terhadap tingkat (Sraddha) keyakinan atau kepercayaan dalam pengembangan budi pekerti. Kesempatan dalam kehidupan ini, yang mendapatkan pengaruh dari triguna, walaupun memiliki pemahaman tingkat keyakinan dalam pengembangan budi pekerti yang berbeda-beda,

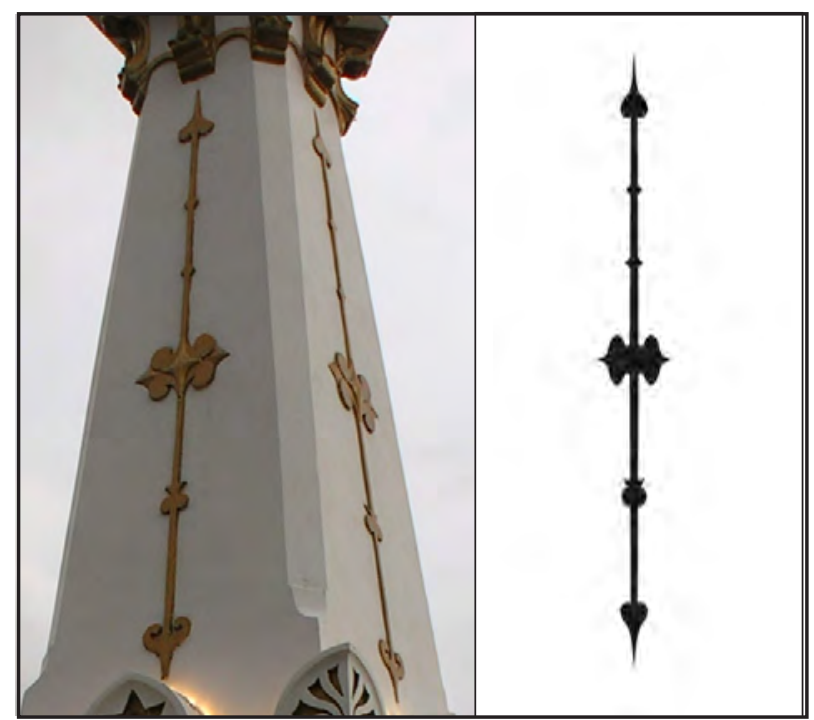

Gambar 9. Anak panah vertkal. Foto dan grafis dibuat oleh penulis pada 9 November 2011. semua ini dapat dipergunakan menjadi modal dasar untuk mengubah segala perilaku ke arah yang lebih baik. Ini dapat terwujud pada saat menentukan pilihan dalam bertindak atau berbuat, apabila selalu dengan mengutamakan sifat sattvam. Adapun sifat rajas dan sifat tamas dipergunakan dalam situasi dan kondisi yang tepat.

Bentuk untiran ini juga disebut sebagai janget kinatelon yang berarti kekuatan dari persatuan. Untiran ini terbuat dari kayu yang memiliki beberapa sifat sekaligus, yang tidak dapat ditiru oleh bahanbahan lain. Pemilihan bahan kayu sebagai puncak Tugu dapat dimaknai sebagai sebuah perbedaan atau ciri khas Yogyakarta.

Perbedaan lain adalah sifat kayu sebagai penangkal petir. Bangunan-bangunan tinggi, baik itu gedung maupun peninggalan sejarah seperti Candi Borobudur atau Candi Prambanan selalu diberi penangkal petir. Hal ini untuk menghindari kerusakan bangunan akibat tersambar petir. Menurut Prayitno dan Darnoko (1994), "kayu memiliki sifat isolasi listrik dan isolasi panas" sehingga Tugu tidak memerlukan logam sebagai penangkal petir.

Pemaknaan kayu yang lain adalah sifat tumbuh kembang dari pohon. Kayu merupakan bagian pohon yang selalu berkembang dari biji hingga menjadi batang besar. Sifat tumbuh dan berkembang diharapkan juga akan menjadi milik Keraton Yogyakarta. Yogyakarta akan terus berkembang dan berbenah diri sehingga menjadi kerajaan yang besar.

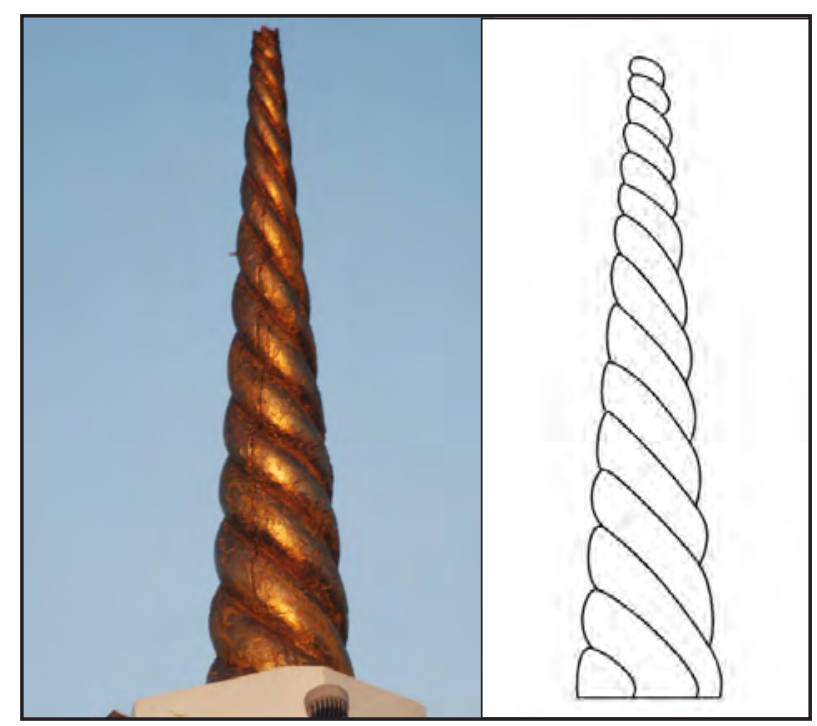

Gambar 10. Untiran yang terletak pada puncak tugu. Foto dan grafis dibuat oleh penulis pada 9 November 2011. 
Prisma segi delapan (gambar 11) merupakan bentuk pengembangan dari segi delapan. Bentuk ini dapat dimaknai sebagai menuju kesempurnaan. Dengan demikian, secara keseluruhan prisma segi delapan dapat dimaknai sebagai delapan watak atau sifat yang mengantar manusia menuju ke kesempurnaan.

Garis-garis yang terdapat dalam tugu membentuk berbagai bidang. Gerak garis ini mampu mengekspresikan dan memberikan gambaran-gambaran yang estetis yang melahirkan makna-makna pada setiap ornamen yang ada pada tugu.

Garis dapat mengekspresikan baik gerak maupun massa. Gerak ini diekspresikan bukan semata-mata oleh penggambaran objek-objek yang sedang bergerak (yang merupakan adaptasi garis pada observasi yang selektif semata), melainkan secara lebih estetis dengan jalan memperoleh gerakan-gerakan yang otonom dari diri sendiri, yaitu dengan menari-nari di halaman dengan enaknya tanpa tujuan reproduktif apa pun (Read, 2000: 20).

Warna emas merupakan warna dari logam mulia; warna mata sapi dan juga warna pusat dari target lima zona Inggris diolahraga cabang memanah. Warna emas sering digunakan sebagai latar belakang oleh seniman sebagai perwakilan surga. Berdasarkan pendapat tersebut, dapat dikatakan bahwa penggunaan warna emas pada puncak tugu maupun ornamen tugu merupakan warna matahari dan perlambang dari surga. Warna emas yang diambil dari warna logam mulia ini menyimbolkan kemewahan dan kekayaan bagi penggunanya, juga menunjukkan kekekalan dan kesetiaan.

Warna emas, menurut Paterson (2004: 179):

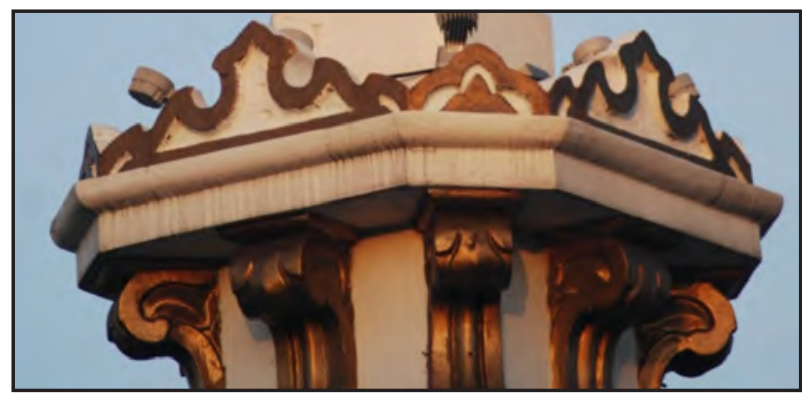

Gambar 11. Prisma segi delapan. Foto diambil oleh penulis pada 9 November 2011
"A deep yellow colour; the colour of the precious metal; the colour of the bulls eye, the centre of the British five zone target in archery; the background colour used by artists to represent heaven; associated in medieval times with the Zodiac sign Leo and with the sun.

Warna emas merupakan warna dari logam mulia; warna mata sapi dan juga warna pusat dari target lima zona Inggris diolahraga cabang memanah. Warna emas sering digunakan sebagai latar belakang oleh seniman sebagai perwakilan surga. Berdasarkan pendapat tersebut, dapat dikatakan bahwa penggunaan warna emas pada puncak tugu maupun ornamen tugu merupakan warna matahari dan perlambang dari surga. Warna emas yang diambil dari warna logam mulia ini menyimbolkan kemewahan dan kekayaan bagi penggunanya, juga menunjukkan kekekalan dan kesetiaan.

Warna yang lain yang menjadi warna tugu adalah warna putih. Warna putih menyimbolkan kesucian. Oleh karena itu, warna putih sering digunakan dalam upacara pernikahan. Putih juga simbol ketepatan, ketidakbersalahan, kebersihan, dan banyak digunakan di rumah-rumah sakit sebagai tanda steril.

Warna cokelat merupakan warna dari tanah dan bumi, melambangkan kepercayaan, kedewasaan, dan daya tahan. Warna natural ini membawa kenyamanan bagi sekelilingnya sehingga banyak digunakan untuk mendekorasi ruangan.

Selain bentuk dan warna, ada pemaknaan lain pada tugu, yaitu berupa prasasti (gambar 13)

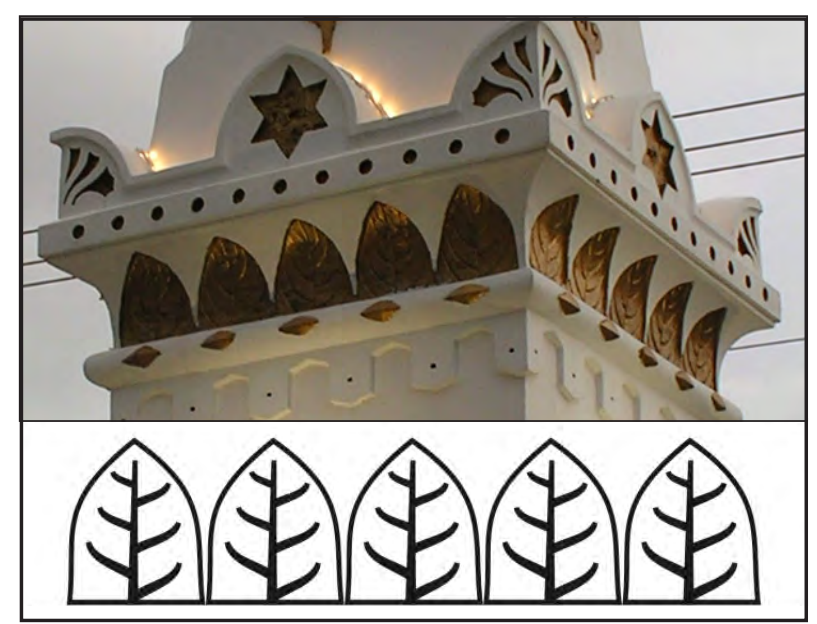

Gambar 12. Motif daun loto. Foto dan grafis dibuat oleh penulis pada 9 November 2011. 
yang menempel pada keempat sisi tugu: (1) Prasasti sebelah selatan bertuliskan wiwara harja manggala praja kaping 7 Sapar Alip 1819. Prasasti ini sebagai penanda kapan tepatnya Tugu Yogyakarta sekarang dibangun untuk menggantikan Tugu Golong-Gilig. Selain itu, wiwara harja manggala dapat diartikan sebagai berikut: Wiwara artinya pintu, harja artinya kesejahteraan, manggala artinya pimpinan dan praja yang artinya raja. Dengan demikian, wiwara harja manggala praja dapat diartikan bahwa tugu merupakan simbol dari pintu kesejahteraan pemimpin, yaitu raja. Pemahaman atau makna prasasti ini berbeda jauh dengan pemahaman Tugu Golong-Gilig, yaitu manunggaling kawulo lan Gusti atau bersatunya antara rakyat, raja dan Tuhan; (2) Prasasti sebelah timur bertuliskan Hingkang Mangayubagya Karsa Dalem Kanjeng Tuan Residen Y. Mullemester. Prasasti ini menunjukkan rasa ikut berbahagia bangsa Belanda atas pendirian kembali tugu. (3) Prasasti sebelah barat bertuliskan Yasan Dalem Hingkang Sinuhun Kanjeng Sultan Hamengku Buwana Hingkang Kaping VII. Prasasti ini menandakan bahwa tugu tersebut didirikan pada masa Sri Sultan Hamengku Buwana VII. Seperti banyak ditulis dalam buku sejarah Keraton Yogyakarta bahwa Tugu Yogyakarta tersebut merupakan renovasi dari Tugu Golong-Gilig yang hancur akibat gempa pada tanggal 10 Juni 1867 atau tanggal 7 Sapar tahun Ehe 1796 yaitu pada masa pemerintahan Sri Sultan Hamengku Buwana VI; (4) Prasasti sebelah utara bertuliskan Pakaryanipun Sinambadan Patih Dalem Kanjeng Raden Adipati Danureja Hingkang
Kaping V Kaundagen Dening Tuan YPF van Brussel Opzichter Waterstaat, yang artinya menandakan bahwa pembangunan tugu tersebut dilaksanakan oleh Adipati Danureja ke-5 dan di bawah komando van Brussel yang saat itu menjabat kepala Dinas Tata Kota dalam sistem pemerintahan Belanda.

\section{Analisa Tahap Ikonologis Tugu Yogyakarta}

Pada tahapan ini, makna yang paling hakiki dan mendasar dari Tugu Yogyakarta benar-benar dipahami. Pemahaman mengenai makna intrinsik yang terdapat dalam sebuah objek diperoleh dengan mengungkapkan prinsip-prinsip dasar yang kemudian dapat menunjukkan perilaku sikap dasar dari sebuah bangsa, kurun waktu, strata sosial, ajakan religius, atau filosofis tertentu.

Feldman mengatakan bahwa gambar visual ditulis dengan didahului bahasa sebagai alat komunikasi. Akan tetapi, seni melampaui komunikasi informasi, tetapi juga mengungkapkan seluruh dimensi kepribadian manusia, atau psikologis dan keadaan tertentu. Seni adalah lebih dari simbol standar dan tanda-tanda yang digunakan karena pembentukan unsur-unsur, seperti: garis, warna, tekstur, mengirim subliminal makna luar informasi dasar.

Pada 10 Juni 1867 atau 4 Sapar Tahun EHE $1284 \mathrm{H}$ atau 1796 Tahun Jawa sekitar pukul 05.00 pagi, Tugu Golong-Gilig rusak terpotong sekitar sepertiga bagian. Musibah itu bisa terbaca dalam candra sengkala - sebuah catatan kata yang bermakna angka tahun - Obah Trusing Pitung Bumi (1796). Kemudian tugu tersebut diperbaiki oleh

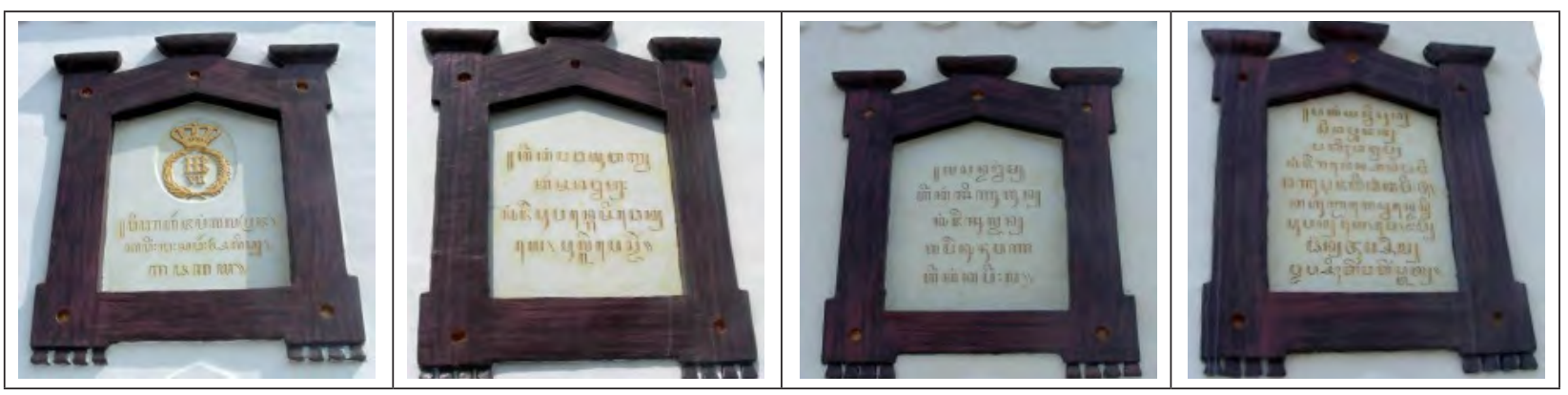

Gambar 13. Prasasti pada keempat sisi tugu (dari kiri ke kanan): sebelah sebelah selatan bertuliskan Wiwara Harja Manggala Praja Kaping 7 Sapar Alip 1819; sebelah timur bertuliskan Hingkang Mangayubagya Karsa Dalem Kanjeng Tuan Residen Y. Mullemester; sebelah barat bertuliskan Yasan Dalem Hingkang Sinuhun Kanjeng Sultan Hamengku Buwana Hingkang Kaping VII; sebelah utara bertuliskan Pakaryanipun Sinambadan Patih Dalem Kanjeng Raden Adipati Danureja Hingkang Kaping V Kaundagen Dening Tuan YPF Van Brussel Opzichter Waterstaat. Foto diambil oleh penulis pada 3 Desember 2011 
Opzichter van Waterstaat/Kepala Dinas Pekerjaan Umum, JWS van Brussel, di bawah pengawasan Pepatih Dalem Kanjeng Raden Adipati Danurejo V. Lalu tugu baru itu diresmikan HB VII pada 3 Oktober 1889 atau 7 Sapar 1819 Tahun Jawa. Oleh pemerintah Belanda, tugu itu disebut De Witte Paal (Tugu Pal Putih). Penamaan tersebut didasarkan pada fungsi tugu sebagai paal atau tonggak yang dicat/dikapur putih hingga tampak jelas dari kejauhan (Upacara Tradisional Jumenengan, 1995: 116). Berangkat dari runtuhnya Tugu Golong-Gilig terebut kemudian dibangun tugu pengganti yang memiliki fungsi tidak jauh dari tugu setelah runtuh. Sebuah tindakan membangun kembali menjadikan tugu berdiri dan dapat dinikmati keberadaan dan keindahannya hingga saat ini.

Bentuk tugu merupakan bentuk yang tersusun atas unsur garis, warna, dan tekstur memberikan maksud dan makna kepada artis dan penonton. Makna-maknanya secara kesatuan bentuk dapat dijabarkan sebagai berikut. Garis besar wilayah
Keraton memanjang lima kilometer ke arah selatan hingga Krapyak dan dua kilometer ke arah utara dan berakhir di tugu. Pada garis ini terdapat garis linier dualisme terbalik sehingga bisa dibaca secara simbolik filosofis. Dari arah selatan ke utara, sebagai lahirnya manusia dari tempat tinggi ke alam fana, dan sebaliknya sebagai proses kembalinya manusia ke sisi Dumadi (Tuhan dalam pandangan Jawa). Keraton sebagai jasmani dengan raja sebagai lambang jiwa sejati yang hadir ke dalam badan jasmani.

Jagad Ageng, yang mengurai tentang hidup dan kehidupan masyarakat, di mana sang pemimpin masyarakat siapapun dia senantiasa harus menjadikan hati nurani rakyat sebagai isteri pertama dan utamanya guna mewujudkan kesejahteraan lahir batin bagi masyarakat dilandasi dengan keteguhan dan kepercayaan bahwa hanya satu pencipta Yang Maha Besar. Jagad Ageng ini digambarkan dengan garis imajiner dari Parangkusuma di Laut Selatan, Keraton Yogyakarta, dan Gunung Merapi. Hal ini

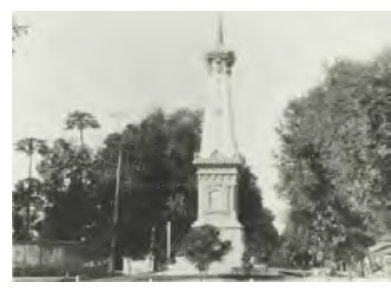

1920

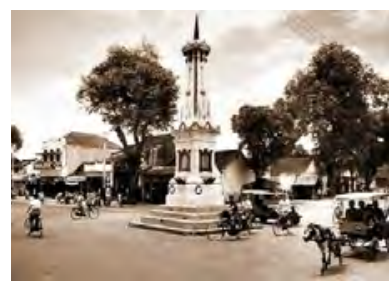

1928

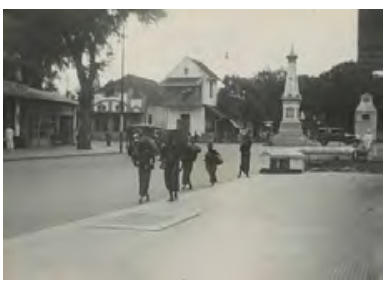

1920

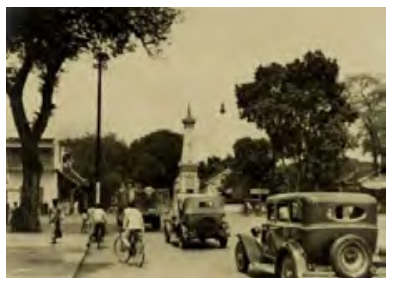

1930

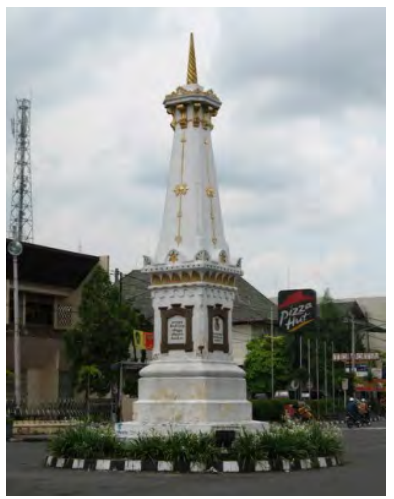

2007

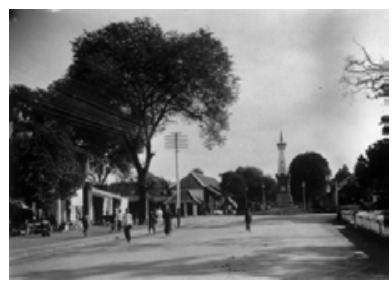

1920

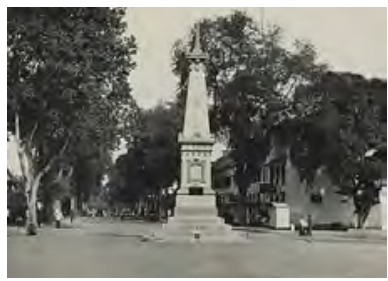

1939

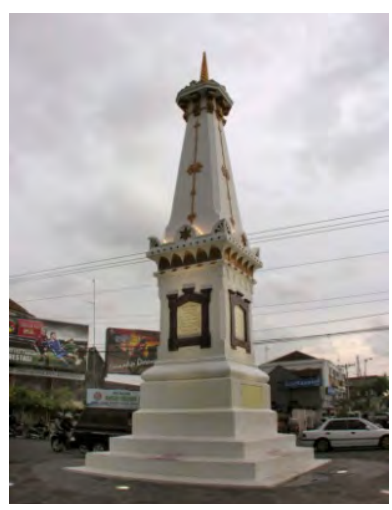

2012

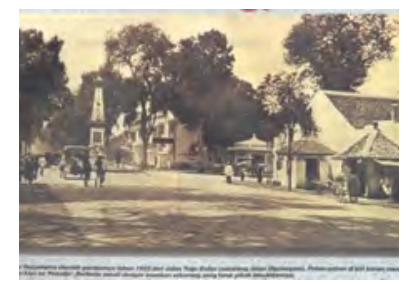

1922

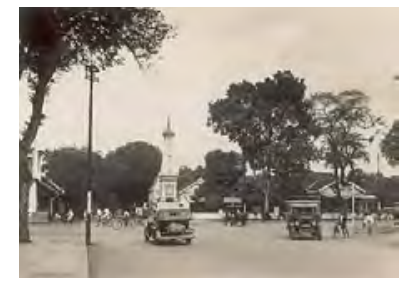

1939

Gambar 14. Perubahan bentuk Tugu sejak tahun 1920 sampai dengan tahun 2012. 
lebih menekankan hubungan antara manusia yang hidup di dunia di mana seorang manusia harus memahami terlebih dahulu hakekat hidup dan kehidupannya sehingga mampu mencapai kesempurnaan hidup (Manunggaling Kawula Gusti).

Hubungan Merapi dengan Keraton sesungguhnya didasarkan pada ajaran dari Sri Sultan Hamengku Buwana I, yaitu ajaran tersebut sesungguhnya merupakan kelanjutan dari ajaran-ajaran nenek moyang yang terdahulu. Ajaran tersebut sering disebut sebagai hamemayu hayuning bawana. Hamemayu hayuning bawana tersebut menjadi suatu filosofi yang menyatakan bahwa manusia sebagai contoh atau kepanjangan tangan dari Tuhan Yang Maha Esa di dunia ini. Dia mempunyai kewajiban menyelamatkan, memperindah, memperlama hidup dunia ini walaupun sangat disadari bahwa dunia ini suatu saat pasti akan hancur. Hayuning itu artinya menghayuhayukan atau memperindah atau menyelamatkan dari kerusakan maka secara filosofi perlu disadari bahwa kekuatan alam itu ada. Kekuatan-kekuatan alam perlu sekali diperhitungkan dalam rangka hubungan manusia dengan Tuhan yang sering disebut sebagai hablun minallah. Manusia juga harus memelihara hubungannya dengan manusia yang lain yang sering disebut sebagai hablun minannas yang bermakna hubungan manusia satu dengan yang lain dan manusia dengan manusia serta alam semesta ini harus dipelihara.

Jagad alit, yang mengurai proses awal-akhir hidup dan kehidupan manusia dengan segala

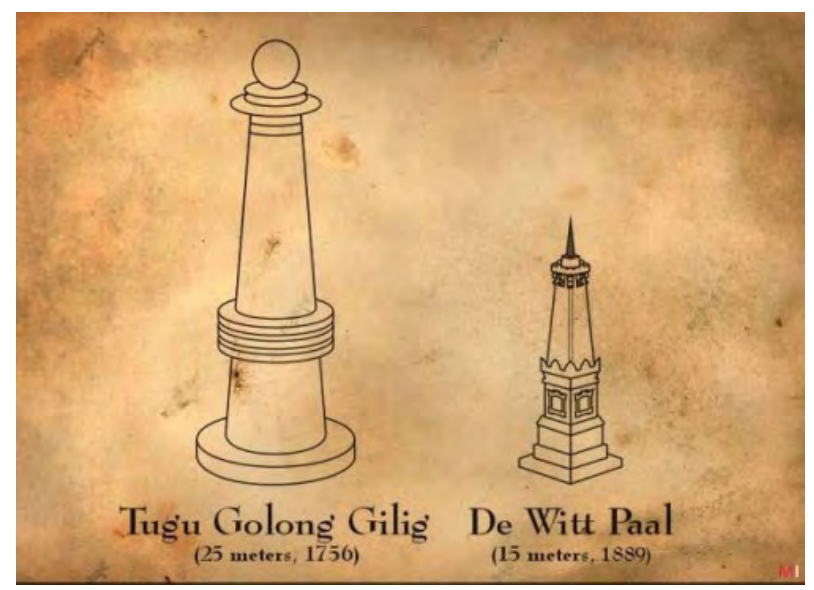

Gambar 15. Tugu Golong-Gilig dan Tugu Yogyakarta Sumber: http://www.jogjawae.com/wp-content/ uploads/2011/og/tugu-golong-gilig.jpg . (Diakses pada tanggal 13 Januari 2012 pukul 2:27:44 AM) perilaku yang lurus sehingga terpahaminya hakikat hidup dan kehidupan manusia, digambarkan dengan planologi Kota Yogyakarta sebagai Kota Raja pada waktu itu. Planologi kota ini membujur dari selatan ke utara berawal dari Panggung Krapyak, berakhir di tugu. Secara sederhana, Tugu perlambangan Lingga (laki-laki) dan Krapyak sebagai Yoni (perempuan). Adapun filosofi Panggung Krapyak ke utara merupakan perjalanan manusia sejak dilahirkan dari rahim ibu, beranjak dewasa, menikah sampai melahirkan anak (Brotodiningrat, 1978). Krapyak merupakan gambaran asal roh-roh. Visualisasi dari filosofi ini diwujudkan dengan keberadaan kampung Mijen (berasal dari kata wiji yang berarti benih) di sebelah utara Panggung Krapyak yang melambangkan benih manusia atau awal mula manusia. Di kanan kirinya terdapat pohon asem dan pohon tanjung. Pohon asem (tamarindus indica) dengan daun yang masih muda bernama sinom melambangkan

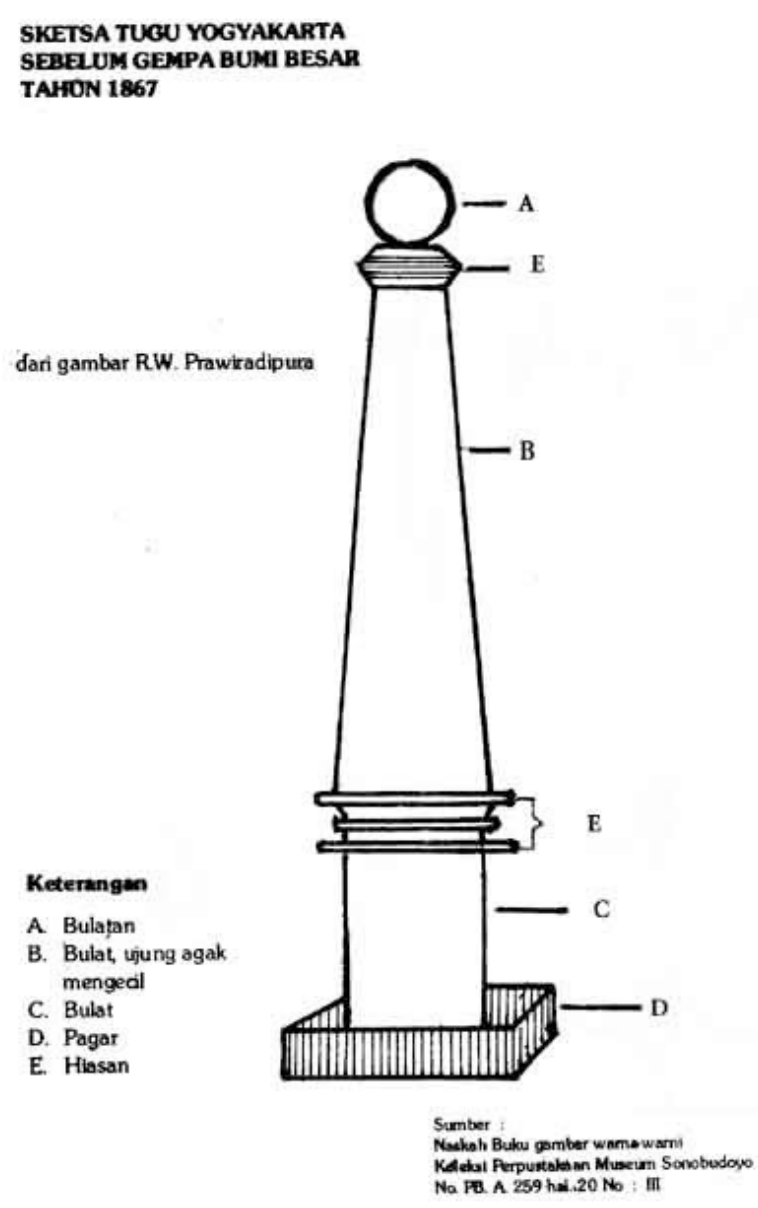

Gambar 16. Sketsa Tugu Yogyakarta sebelum gempa bumi besar tahun 1867. Sumber: Buku Gambar WarnaWarni, koleksi Museum Sono Budoyo Yogyakarta. 
gadis yang masih anom (muda) selalu nengsemaken (menarik hati), maka selalu disanjung. Visualisasi dari penyanjungan ini diwujudkan dengan pohon tanjung (mimusopselengi).

Keberadaan Panggung Krapyak dan Tugu sebagai lingga dan yoni melambangkan arti proses terjadinya manusia, mulai ketika masih berada di alam arwah (tempat tinggi), sampai lahir ke dunia lantaran ibu dan bapak. Di sini keraton sebagai badan jasmani manusia, sedangkan raja atau sultan adalah lambang jiwa sejati yang hadir ke dalam badan jasmani. Hal ini menekankan hubungan timbal balik antara Sang Pencipta dan manusia sebagai ciptaan-Nya (Sangkan Paraning dumadi).

Tugu merupakan salah satu poros (sumbu) filosofis kota Yogyakarta. Poros (sumbu) filosofis yang lain adalah Gunung Merapi, Keraton, Panggung Krapyak, dan Laut Selatan. Penciptaan poros filosofis ini selaras dengan konsep Tri Hita Karana dan Tri Angga (Parahyangan, Pawongan, dan Palemahan atau Hulu, Tengah, dan Hilir serta nilai Utama, Madya, dan Nistha). Secara simbolis filosofis poros ini melambangkan keselarasan dan keseimbangan hubungan manusia dengan Tuhannya (hablumminalloh), manusia dengan manusia (hablumminannas) maupun manusia dengan alam termasuk lima anasir pembentuknya, yakni api (dahana) dari Gunung Merapi, tanah (bantala) dari bumi Ngayogyakarta dan air (tirta) dari Laut Selatan, angin (maruta), dan angkasa (either). Poros filosofis ini juga merupakan simbol dari konsep filosofi sangkan paraning dumadi dan

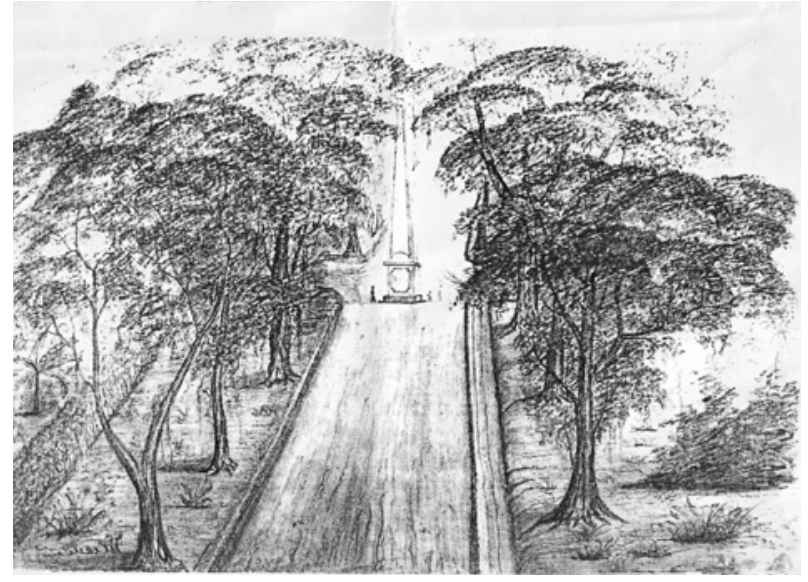

Gambar 17. Lukisan Pensil Tugu Golong-Gilig Tahun 1846 Sumber: K.R.T. H. Djatiningrat, S.H., Pengageng Tepas Dwarapura Ngayogyakarta Hadingrat, 12 Desember 2011, Keraton Kilen Yogyakarta manunggaling kawula Gusti. Tugu dan Panggung Krapyak merupakan simbol lingga dan yoni yang melambangkan kesuburan.

Dasar kepercayaan Jawa atau Javanisme adalah keyakinan bahwa segala sesuatu yang ada di dunia ini pada hakikatnya adalah satu atau merupakan kesatuan hidup. Javanisme memandang kehidupan manusia selalu terpaut erat dalam kosmos alam raya. Dengan demikian, kehidupan manusia merupakan suatu perjalanan yang penuh dengan pengalaman yang religius.

Fakta, bahwa relasi dunia mikro dan makro adalah kebertautan yang kental dalam penghayatan manusia terhadap dirinya dan semestanya. Sehingga seorang manusia berpikir, bertindak, dan berkarya tidak bakal terlepas dari relasi-relasi semesta mikro dan makro. Dalam kasus-kasus kebudayaan, manusia adalah pelaku budaya, sekaligus melakukan proses budaya, dan hidup dalam kebudayaan yang dihasil-

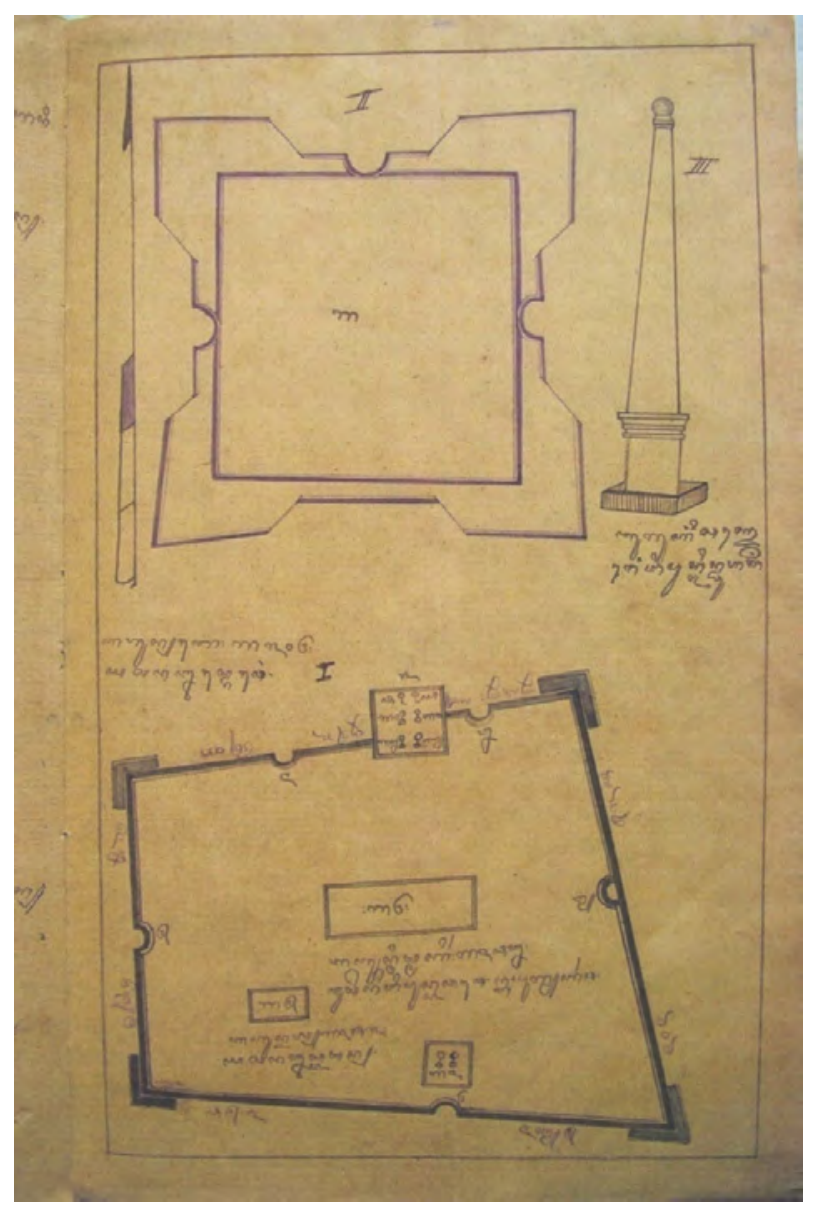

Gambar 18. Tugu Golong-Gilig dan Gambar Tampak Atas Sumber: Buku Gambar Warna-Warni, Koleksi Museum Sono Budoyo Yogyakarta 
kannya. Kebudayan sebagai proses belajar manusia merangkum bentuk-bentuk penghayatan inhern terhadap apa yang ada dalam dirinya dan apa yang ada di luar dirinya. Hubungan penghayatan tersebut menandai sebuah proses keteraturan semesta. Kasus seperti ini terdapat pula dalam proses kreasi seni rupa, dimana seni rupa adalah karya manusia (perupa), sekaligus ia berada di dalamnya, dan dapat menikmati atau dinikmati keberadaannya (Mamannoor, 2002: 125).

Manusia sebagai pusat dari sebuah budaya, yaitu sebagai pelaku budaya, memiliki beberapa penghayatan. Hal ini terwujud dalam berbagai alam pikiran orang Jawa yang merumuskan bahwa kehidupan manusia berada dalam dua kosmos (alam), yaitu makrokosmos dan mikrokosmos. Makrokosmos dalam pikiran orang Jawa adalah sikap dan pandangan hidup terhadap alam semesta yang mengandung kekuatan supranatural dan penuh dengan hal-hal yang bersifat misterius. Adapun mikrokosmos dalam pikiran orang Jawa adalah sikap dan pandangan hidup terhadap dunia nyata. Tujuan utama dalam hidup adalah mencari dan menciptakan keselarasan atau keseimbangan antara kehidupan makrokosmos dan mikrokosmos.

Dalam makrokosmos pusat alam semesta adalah Tuhan. Alam semesta memiliki hirarki yang ditujukan dengan adanya jenjang alam kehidupan orang Jawa dan adanya tingkatan dunia yang semakin sempurna (dunia atas-dunia manusiadunia bawah). Alam semesta terdiri dari empat arah utama ditambah satu pusat, yaitu Tuhan yang mempersatukan dan memberi keseimbangan.

Sikap dan pandangan terhadap dunia nyata (mikrokosmos) tercermin pada kehidupan manusia dengan lingkungannya, susunan manusia dalam masyarakat, tata kehidupan manusia sehari-hari, dan segala sesuatu yang nampak oleh mata. Dalam menghadapi kehidupan manusia yang baik dan benar di dunia ini tergantung pada kekuatan batin dan jiwanya.

Bagi orang Jawa, pusat di mikrokosmos ada pada raja, Tuhan adalah pusat makrokosmos, sedangkan raja adalah perwujudan Tuhan di dunia sehingga dalam dirinya terdapat keseimbangan berbagai kekuatan alam. Jadi, raja adalah pusat komunitas di dunia seperti halnya raja menjadi mikrokosmos dari Tuhan dengan keraton sebagai kediaman raja. Keraton merupakan pusat keramat kerajaan dan bersemayamnya raja karena raja merupakan sumber kekuatan-kekuatan kosmis yang mengalir ke daerah dan membawa ketentraman, keadilan, dan kesuburan.

Pemahaman makrokosmos dan mikrokosmos ini oleh orang Jawa memandang Tuhan sebagai pusat makrokosmos diwujudkan dalam bentuk ornamen tugu ataupun bentuk-bentuk yang menjadi unsur pembentuk tugu, yang bermakna tujuan akhir dari manusia adalah Tuhannya. Manusia sebagai makhluk sosial yang hidup di alam semesta dengan segala bentuk aktivitas dan keragaman budaya mempercayai adanya pencipta alam semesta, yaitu Tuhan. Manusia hidup karena adanya Tuhan dan akan kembali kepada Tuhan. Manusia lahir, hidup kemudian mati. Berawal dari Tuhan dan akan kembali kepada Tuhan. Hal inilah yang menjadikan manusia harus selalu mengingat Tuhannya dan harus selalu memiliki kepasrahan kepada Tuhannya dan kepercayaan terhadap Tuhan.

Dalam konteks mikrokosmos, tugu bermakna seseorang raja sebagai perwujudan Tuhan di dunia, merangkul dan mengajak masyarakatnya untuk selalu bersatu menghancurkan dan memusnahkan penjajahan. Hal ini dapat pula dimaknai sebagai penyatuan antara rakyat dengan Tuhan yang diwakili oleh raja. Dengan demikian, secara makrokosmos dan mikrokosmos, manunggaling kawulo lan Gusti bisa diartikan sebagai bentuk penyatuan antara rakyat, raja, dan Tuhannya. Konsep tersebut menjadi dasar filosofi makna Tugu Golong-Gilig. Belanda sangat takut dengan filosofi tersebut sehingga ketika membangun kembali tugu dibuat dalam bentuk seperti saat ini. Pemahaman-pemahaman itu oleh Belanda dihapuskan dan diganti dengan bentuk-bentuk prasasti yang bermakna kemuliaan hanya milik raja. Rakyat dan raja tidak lagi berjalan bersama menuju ke kemanunggalan, tetapi kesejahteraan dan kemanunggalan hanyalah milik raja.

Hal serupa juga diungkapkan oleh Djatiningrat, Pengagem Tepas Dwarapura Ngayogyakarta Hadingrat. Dikatakannya bahwa tugu saat ini ber- 
beda makna dengan Tugu Golong-Gilig. Saat ini lebih kepada kesejahteraan yang ditujukan hanya bagi raja dan bukan lagi untuk raja dan rakyatnya. Filosofi manunggaling kawula lan Gusti telah hilang dan tidak tercermin pada tugu saat ini. Sehingga bagi Keraton, tugu saat ini tidak bermakna. Tugu bukan lagi menjadi salah satu simbol keraton tetapi lebih pada ikon Kota Yogyakarta saja.

Fakta lain yang ditemu di lapangan adalah posisi tugu yang tidak berada tepat terhadap arah utara magnet bumi. Setelah dilakukan pengukuran dengan menggunakan alat pengukur koordinat posisi bangunan menggunakan Global Positioning System (GPS) Garmin Map 60 Csx dan menggunakan Theodolite Topcon DT-104, hasilnya menunjukkan posisi tugu berada di dua derajat 58 menit 40 detik dari arah utara magnet. Posisi serong tugu terhadap kutub utara juga dapat dilihat melalui satelit dengan Google Earth 6 Operating System Windows 7. Berdasarkan gambar dari satelit ditemukan posisi tugu berada di Latitude 746'58.64"S dan Longitude $110^{\circ} 22^{\prime} 0.77^{\prime \prime} \mathrm{E}$ dari kutub utara magnet.

Posisi tugu ini dapat dimaknai sebagai sebuah penentangan secara halus Keraton Yogyakarta terhadap pemerintahan Belanda. Pihak Keraton tidak sepenuhnya mengikuti apa yang diinginkan oleh Belanda. Penentangan ini juga terlihat dari pemaknaan posisi serong sebagai kiblatnya orang melakukan salat. Agama Islam merupakan agama yang dipercaya pihak keraton, sedangkan agama yang dianut oleh bangsa Belanda adalah Katholik atau Kristen. Dalam agama mereka, letak posisi gereja atau tempat ibadah tidak mengarah ke arah kiblat. Adapun Islam untuk beribadah selalu mengarah ke arah kiblat. Dengan demikian, posisi serong tugu secara tidak langsung menjadi suatu bentuk penentangan terhadap pemerintah Belanda.

\section{Simpulan}

Dilihat dari bentuknya, tugu memiliki kecenderungan bentuk yang masif dan formal. Tugu Yogyakarta menggunakan unsur-unsur seni rupa berupa garis, titik, dan bidang sebagai dasar pembuatannya sehingga memunculkan maknamakna. Konsep manunggaling kawulo lan Gusti menjadi dasar filosofi makna Tugu Golong-Gilig dan menjadi ketakutan Belanda. Pemahamanpemahaman itu oleh Belanda dihapuskan dan diganti dengan bentuk-bentuk prasasti yang bermakna kemuliaan hanya milik raja.

Untiran yang terbuat dari kayu menunjukkan bahwa teknologi konstruksi bangunan zaman ketika didirikannya tugu masih sederhana, tetapi tidak mengabaikan keamanan bangunan. Bahan kayu yang digunakan sebagai untiran (puncak tugu) dapat difungsikan sebagai penangkal petir.

Dalam hal makna, tugu juga telah berubah dan mulai kehilangan nilai kesakralannya atau mengalamai disakralisasi. Hal ini dibuktikan dengan banyaknya poster-poster di sekitar tugu dan seringnya tugu dijadikan sebagai ajang berfotofoto ataupun pusat kegiatan berdemonstrasi.

Setelah dilakukan pengukuran dengan menggunakan alat pengukur koordinat posisi bangunan menggunakan Global Positioning System (GPS) Garmin Map 60 Csx dan menggunakan Theodolite Topcon DT-104, posisi tugu serong terhadap kutub utara. Posisi ini juga dapat dilihat melalui satelit dengan Google Earth 6 Operating System Windows 7. Berdasarkan gambar dari satelit ditemukan posisi tugu berada di Latitude 746'58.64"S dan Longitude $110^{\circ} 22^{\prime} 0.77^{\prime \prime}$ E dari kutub utara magnet.

\section{Ucapan Terima Kasih}

Diucapkan terima kasih kepada: (1) Museum Sono Budaya, (2) K.R.T. H. Djatiningrat, S.H., Pengagem Tepas Dwarapura Ngayogyakarta Hadiningrat Keraton Kilen Yogyakarta, (3) Raden Riyo Yogo Kanowo Staf Humas Keraton di Yogyakarta, dan Sumitro Kerabat Puro Pakualaman.

\section{Kepustakaan}

Brotodiningrat, KPH. 1978. Arti Kraton Yogyakarta. Yogyakarta: Museum Kraton Yogyakarta.

Feldman, Edmund Burke. 1967. Art as Image and Idea. New Jersey: Printice-Hall Inc. Englewood Cliffs.

Panofsky, Erwin. 1955. Meaning In The Visual Arts. Chicago: The University of Chicago Press.

Paterson, Ian. 2009. A Dictionary of Colour: A Lexicon of the Language of Colour. USA: University 
of California.

Prayitno, T.A. dan Darnoko. 1994. "Karakteristik Papan Partikel dari Pohon Kelapa Sawit”. Berita PPKS 2. Medan: Pusat Penelitian Kelapa Sawit.

Purwadi dan Djoko Dwiyanto. 2006. Filsafat Jawa, Ajaran Hidup yang Berdasarkan Nilai Kebijaksanaan Tradisional. Yogyakarta: Panji Pustaka.

Sabdacarakatama, Ki. 2009. Sejarah Keraton Yogyakarta. Jakarta: PT Buku Kita.

Zoetmulder, P.J. 1991. Manunggaling Kawula Gusti: Pantheisme dan Monisme dalam Sastra Suluk Jawa. Jakarta: PT Gramedia Pustaka Utama.

\section{Majalah}

Buku Gambar Warna-Warni.. tt. Koleksi Museum Sono Budoyo. Yogyakarta. Upacara Tradisional Jumenengan. 1995

\section{Informan}

K.R.T. H. Djatiningrat, S.H. Pengagem Tepas Dwarapura Ngayogyakarta Hadingrat, 12 Desember 2011, Keraton Kilen Yogyakarta.

Raden Riyo Yogo Kanowo (40 tahun). Staf Humas

Keraton Yogyakarta, 17 Desember 2011

Keraton Yogyakarta.

Sumitro (55 tahun). Kerabat Puro Pakualaman, 20

Desember 2011, Ndalem Puro Pakualaman

\section{Pustaka Laman}

http://2.bp.blogspot.com/_VmvJFum1TCU/ TO9XCDAkz8 I/AAAAAAAAAAs/ J1JOy33Q7iA/s1600/Tugu-doeloe640x480. jpg. (Diakses pada 3/2/2012 pukul 1:27:34 AM)

http://2.bp.blogspot.com/-7OG43Clpfyg/Ta6_ ILw3dNI/AAAAAAAAAvU/fiT45Eytbso/ s1600/12.JPG. (Diakses pada 3/2/2012 pukul 3:09:46 AM)

http://2.bp.blogspot.com/-8ybXmmlVKdU/

Tf2jvG_V91I/AAAAAAAAAKI/ $\mathrm{C}$ e U f 4 o $8 \mathrm{R} 3 \mathrm{ak} / \mathrm{s} 1600$ / Toegoe+te+Jogjakarta+1930.jpg. (Diakses pada 3/2/2012 pukul 2:32:48 AM)

http://3.bp.blogspot.com/-Bk3_ S O U H B 5 E / T V v h t a J T R v I / AAAAAAAABiU/rSNEP_6gH7s/s1600/ GONDOLAYU+1937.jpg. (Diakses pada 3/1/2012 pada 12:59:16 PM)

http://4.bp.blogspot.com/_4P4TxS_H3_I/

TS 7 f59Akyg I/ A A A A A A A A N 0 / hTKeUqfOhr0/s1600/4.JPG. (Diakses pada 3/2/2012 pukul 3:13:55 AM)

http://4.bp.blogspot.com/_-ecjC8vJ7a8/

TEPW MxaL 8 UI/AAAAAAAAAAc/ tQhhk2RjFJE/s1600/MatadjokjaTugu.jpg (Diakses pada 3/1/2012 pukul 1:01:55 PM) http://acara-jogjatv.blogspot.com/2011/04/tugugolong-gilig-1.html (Diakses pada 2/12/2012 pukul 9:38:34 AM)

http://jogjatvupload.blogspot.com/2011_01_01_ archive.html (Diakses pada 2/2/2012 pukul 9:45:04 PM)

http://kfk.kompas.com/image/preview/aW1hZ2V zL3Nma19waG90b3Mvc2ZrX3Bob3Rvc18x MjgzMTEyNDkyXzFLYmIxR25YLmpwZw \%3D\%3D.jpg (Diakses pada 3/1/2012 pukul 1:16:48 AM)

http://listianash.files.wordpress.com/2008/09/ toegoe2.jpg (Diakses pada 3/2/2012 pukul 2:53:34 AM)

http://sutris.web.id/wp-content/uploads/2012/01/ Tentang-Tugu-Yogyakarta.jpg (Diakses pada 3/1/2012 pukul 1:52:28 AM)

http://upload.wikimedia.org/wikipedia/ com mons/c/ c 1 / COLLECTIE_ TROPENMUSEUM_De_Toegoe_of_ Witte_Paal_in_Jogjakarta_TMnr_60007932. jpg (Diakses pada 3/2/2012 pukul 2:26:41 AM)

http://www.jogjawae.com/wp-content/ uploads/2011/09/tugu-golong-gilig.jpg (Diakses pada 1/13/2012 pukul 2:27:44 AM) http://www.jogjawae.com/wp-content/ uploads/2011/09/tugu-golong-gilig.jpg (Diakses pada 3/2/2012 pukul 3:08:20 AM) http://www.skyscrapercity.com/showthread. php? $\mathrm{p}=88724012$ (Diakses pada 2/24/2012 pukul 9:06:58 AM). 